Abstracta Iranica Abstracta Iranica

Revue bibliographique pour le domaine irano-aryen

Volume 22 | 2001

Comptes rendus des publications de 1999

\title{
Culture, Society and Politics in Central Asia and India. New Delhi, Sbipra Publications, 1999, 303 p.
}

\section{Suchandana Chatterjee}

\section{(2) OpenEdition}

1 Journals

Édition électronique

URL : http://journals.openedition.org/abstractairanica/37297

DOI : 10.4000/abstractairanica.37297

ISSN : 1961-960X

\section{Éditeur :}

CNRS (UMR 7528 Mondes iraniens et indiens), Éditions de l'IFRI

\section{Édition imprimée}

Date de publication : 15 mai 2001

ISSN : 0240-8910

\section{Référence électronique}

Suchandana Chatterjee, "Culture, Society and Politics in Central Asia and India. New Delhi, Sbipra Publications, 1999, 303 p. », Abstracta Iranica [En ligne], Volume 22 | 2001, document 626, mis en ligne le 17 février 2010, consulté le 13 octobre 2020. URL : http://journals.openedition.org/abstractairanica/ 37297 ; DOI : https://doi.org/10.4000/abstractairanica.37297

Ce document a été généré automatiquement le 13 octobre 2020.

Tous droits réservés 


\title{
Culture, Society and Politics in Central Asia and India. New Delhi, Sbipra Publications, 1999, $303 \mathrm{p}$.
}

\author{
Suchandana Chatterjee
}

1 This volume is a collection of papers that were presented during an international seminar entitled Culture, Society and Politics in Central Asia, organized by the India International Centre on 20-23 November 1998 in collaboration with the Indian Council of Cultural Relations. The contributors in this volume have focussed mainly on civilizational contact between South, Central and West Asia. The thrust of the papers is on the Silk Route, which not only served as a conduit of trade, but also of men and ideas. Scholars from India (Mansura Haidar, Radha Raina, Fida M. Hassnain, R. C. Agrawal), Pakistan (Ahmad Hasan Dani), Central Asia (Alokhan Afsakhzod, M. Khairullaev, Anageldy Gubaev) have written on religion, arts and crafts in the precolonial period and analysed the nature of culture exchange throughout Eurasia. The underlying emphasis of these papers was that there were unifying elements in the culture of the region that brought together missionaries, traders, pilgrims who travelled through the 'first transcontinental highway' known as the Silk Road. The syncretism of the past years, the unifying bonds of Buddhist, Christian, Hindu and Islamic faiths waned with the imposition of colonial rule in the 19th century. In a few cases like that of the jadids, argues Shams-ud-Din, there were attempts to integrate Western aspects of education. These were what he called 'native responses'. Devendra Kaushik's paper points to the inevitability of collision between the colonial powers and their subjects in Central Asia. The dominance of state-mechanism was reflected in the Soviet epoch too. Farhad Atai of Iran points to the political culture in Central Asia under Soviet rule. He indicates how art, culture and literature was state-managed by the Soviet administrators in Moscow. Ajay Patnaik's paper touches on more complex problems of ethnicity in Central Asia during the 1990's. His paper points to the social problems afflicting Central Asia during the last 10 years. The papers in the volume stress that symbiosis and conflict of cultures go hand in hand. While some point to the Great Game rivalries of the imperial masters during the 19th century, others point to 
regional tensions in the late 20th century due to ethnic and clan differences. There is also the recurrent interest among scholars to analyse the 'new great game' of the late 20th century, i.e. the competition for new trade routes (oil and gas links via the PersoAfghan sector). Others like P. Stobdan and E. M. Eben of Qazaqstan are hopeful about regional cooperation. There are indications about India's security interests in the region. There are some interesting reflections about expressions of national identity in Central Asia, particularly Uzbekistan and Turkmenistan. In Uzbekistan, the use of revised textbooks as the medium of edep or adab is referred to. On the whole, in this book, there are opinions that highlight on revival of civilizational contacts and the need to minimise tensions of geopolitics, ethnicity, strategy and defence of borders in Central Asia and its neighbourhood. Contents of the book as follows: Dani, Ahmad Hasan, "Cultural Links between Central Asia and South Asia », pp. 6-16; Patnaik, Nityanand, "Ethnic and Cultural Interaction between Central Asia and India ", pp.17-23 ; Haidar, Mansura, «Exchanges and Interactions in the Field of Fine Arts, Handicrafts and Technology ", pp. 80-97; Shamsuddin, "The Jadidist Movement in Central Asia: The Natives' Response to Russian Cultural Penetration», pp.98-108; Khan, Aimat Hayat, "Political Contacts between Central Asia and The Indian SubContinent ", pp.128-152 ; Patnaik, Ajay, "Socio-Cultural Changes in Post-Soviet Central Asia », pp.198-210 ; Stobdan, P., «India and Central Asia: Perspectives for Regional Cooperation», pp. 239-254; Ross, Masood Hussain, «Cultural Evolution of Islam in Central Asia: Impact on Society and Politics ", pp. 264-277; Warikoo, K., «Revival of Ethno-Cultural Heritage in Contemporary Central Asia: Relevance for India ", pp. 278-283 ; Dixit, J. N., "Culture, Society and Politics in Central Asia», pp. 284-290.

\section{INDEX}

Thèmes : 13.3. Asie centrale

\section{AUTEURS}

\section{SUCHANDANA CHATTERJEE}

Maulana Abul Kalam Azad Institute of Asian Studies - Calcutta (Inde) 